\title{
Partum and postpartum characteristics on the postpartum rebreeding in beef cattle
}

\author{
GUILHERME JONER ${ }^{1}$, DARI C. ALVES FILHO ${ }^{2}$, IVAN L. BRONDANI ${ }^{2}$, DANIELE BORCHATE ${ }^{2}$, JOHN \\ L. KLEIN ${ }^{2}$, CAMILLE C. DOMINGUES ${ }^{2}$, LEONEL S. RODRIGUES ${ }^{2}$ and DIEGO S. MACHADO ${ }^{2}$
}

${ }^{1}$ Universidade Federal do Pampa, Rua 21 de Abril, 80, 96450-000 Dom Pedrito, RS, Brazil ${ }^{2}$ Universidade Federal de Santa Maria, Departamento de Zootecnia, Avenida Roraima, 1000, Camobi, 97105-900 Santa Maria, RS, Brazil

Manuscript received on December 11, 2017; accepted for publication on January 23, 2018

\begin{abstract}
The objective was to evaluate the influence of calving and postpartum characteristics, measured in different genetic predominance, on the postpartum rebreeding. Were evaluated 437 partum from cows that received feeding management consisting of a forage base of the native field and the mating season consisted of 90 days. The measurements were used from the data base (age of cow, genetic predominance, body weight, body condition score and date of calving) of the cows in the partum and postpartum period. The variables were submitted to analysis of multiple variances, multiple regression, correlation and cluster. Already the groups formed by cluster analysis were submitted to analysis of variance and $\mathrm{F}$ test and the means, compared by Student's t-test, $\alpha=0.05$ probability. The increase in the mean at 0.14 points in the body condition score at calving and the occurrence of calving 9 days earlier at the calving season gives the Charolais genetically predominant cows repeat calves. The Nellore genetic predominance when they calved with similar body condition score ( 2.32 points) and showed a negative body weight gain at weaning $(-3.0 \mathrm{~kg}$ and $-2.1 \mathrm{~kg})$ showed different behaviors, where they did not repeat the offspring, when they calved and weaned with smaller body weight.
\end{abstract}

Key words: calving period, calving season, crossing, multiparous, reproductive efficiency.

\section{INTRODUCTION}

The improvement of the reproductive efficiency in bovine herds is recommended to reduce the age at the first service, to reduce the interval between calving and to increase the amount of $\mathrm{kg}$ of calf weaned/cow/year.

The greatest obstacle to improve reproductive indexes is related to the inadequate nutrition of the

Correspondence to: Guilherme Joner

E-mail: guilhermejoner@unipampa.edu.br

* Contribution to the centenary of the Brazilian Academy of Sciences. animals involved in the breeding process (Recoules et al. 2013). Usually these animals are managed in Brazil in grazing areas that have low nutritional value and variations in annual vegetative growth (Tanure et al. 2011), requiring knowledge of pastoral techniques. As a result, poor reproductive performance reflecting in turn the production rates of the herd, resulting in lower yields of the activity. The nutritional adequacy of the animal can be observed through animal performance, in characteristics such as body weight gain and body condition score. Being the body condition score quantifying body reserves (Moraes et al. 2013), 
which are used for maintenance, tissue growth, reproduction and lactation. In adipose tissue there is also leptin formation, which will act on the hormonal release determining the cyclicity of the female (Priyadarshini et al. 2015). Therefore, the female's cyclicity will be conditioned to reserve body fat or a gradual increase in body fat deposition.

The maintenance of body weight and body condition score, at satisfactory levels of reproduction, are different for each animal category, thus requiring heterogeneous alimentary management. Under this prism, heifers that are entering the reproductive life have less nutritional demand than calving (primiparous and multiparous) cows, since they still need to supply the calf (suckling). Therefore, they require nutritional quality (pre and postpartum), to enter the mating season and to postpartum rebreeding (Mulliniks et al. 2012). Silveira et al. (2014) corroborate this assertion because they found that low pregnancy rate is due to the pre and postpartum food restriction that leads the animal to low birth weight and prolonged postpartum anestrus interval.

Thus, the monitoring of the animals becomes important to determine possible actions that the rural manager can take to seek the correct body weight and body condition score of the animals, increasing their reproductive efficiency. We hypothesized that the higher body weight and body condition score of the cows at calving and postpartum are related to the rearing of calves. Still different values were expected for the variables according to genetic predominance. Therefore, the objective of this study was to evaluate the influence of the characteristics of the calving and postpartum, measured in different genetic predominance, on the postpartum rebreeding.

\section{MATERIALS AND METHODS}

The procedures are in accordance with the Institutional committee for the Care of Animals in Experimentation (Federal University of Santa
Maria, UFSM). The study was carried out at the Cattle Breeding Laboratory of the Department of Animal Science of the Federal University of Santa Maria, city of Santa Maria, located in the Central Depression of the State of Rio Grande do Sul (Brazil), at an average elevation of $95 \mathrm{~m}$ at $29^{\circ} 43^{\prime}$ south latitude and $53^{\circ} 42^{\prime}$ west longitude.

The climate of the region is " $\mathrm{Cfa}$ " (humid subtropical), according to Köppen classification, with annual average rainfall of $1650.9 \mathrm{~mm}$, annual average temperature $19.2{ }^{\circ} \mathrm{C}$, with the minimum and maximum average temperature of 9.7 and $29.9{ }^{\circ} \mathrm{C}$ respectively, in the months of August and January. The sunshine is 2212 hours per year and relative humidity 73\% (Alvares et al. 2013).

All heifers evaluated were from early weaning (75 days), and were then managed in one of the pastures in the first summer (Elephantgrass, Millet, Alexandergrass or Tifton 85) followed by black oats + ryegrass, both with energetic supplementation ( $1 \%$ of body weight). In the second summer and throughout the reproductive life, they received nutritional management of the herd, that is, native field forages (average animal load of $350 \mathrm{~kg} / \mathrm{ha}$ ) with mineral supplementation based on sodium chloride and dicalcium phosphate. The existing native field has the characteristics of the presence of shrubs and the great existence of plants with cespitate habit and is in the transition area of the Pampa and Atlantic Forest biome. The management area of the herd has an invasion of Annoni grass (Eragrostis plana Nees), a plant that is undesirable because it has a low nutritional value and has a very aggressive habit on the other plants, due to its allelopathic capacity, reducing the biodiversity of the system. More information about characteristics of the productive system adopted in the farm can be found in Silveira et al. (2014).

Heifers entered the reproductive process with a mean age of $26 \pm 1$ months. The female mating season was 90 days, the first 45 days (01/12 to 13/01) for artificial insemination and the other 45 
days (14/01 to 28/02) for the natural mountaineering with bulls (1: 30-40). The diagnosis of pregnancy was performed by rectal palpation, 60 days after the end of the mating season. The approximate calving period was 15 September (considered "day 1" at the calving season) to 15 December and weaning at the mean age of 75 days postpartum. Body weight gain from calving to weaning (BWGCW) was calculated by the difference between body weight at weaning and body weight at calving.

In the present study, 437 cows born between the years 2004 and 2010 , belonging to $4^{\text {th }}(11 / 16 \mathrm{Ch}$ $5 / 16 \mathrm{Ne} ; 11 / 16 \mathrm{Ne} 5 / 16 \mathrm{Ch}), 5^{\text {th }}(21 / 32 \mathrm{Ch} 11 / 32 \mathrm{Ne}$; $21 / 32 \mathrm{Ne} 11 / 32 \mathrm{Ch}$ ) crossover generations and purebred animals defined that were divided according to genetic predominance (Charolais or Nellore).

The following measurements of the cows were used in the database: calving condition (pregnant or empty); genetic predominance (Charolais or Nellore); age of cow; date of calving; weight (at calving and weaning); body condition score at calving. Body weight and body condition score at calving were obtained within the first 24 hours after calving. The body condition score (BCS) followed the scale from 1 to 5 , being: $1=$ very lean, $2=$ lean, $3=$ average, $4=$ fat and $5=$ very fat (Lowman et al. 1973). From the date of calving was obtained within the calving season, being considered September 15 as "day 1". The information collected was recorded in physical worksheets and later passed to spreadsheets, and the original worksheets were filed in a specific room.

Statistical package SAS ${ }^{\circledR}$ (SAS 2009) was used for analysis. The variables were submitted to analysis of multiple variance (MANOVA) by PROC GLM procedure, and the Wilks' Lambda test was verified with $\alpha=0.05$ probability. To verify the homogeneity of the variances, the Levene test was used and the Kolmogorov-Smirnov test was used to test the normality of the residuals, with $\alpha=0.05$ significance. For the variables that did not follow normal distribution, constants were used to reach the normality of the residuals, being necessary the use of the constants: squared values for body condition score at birth and log for the variable body weight at birth. The correlation between the variables studied was performed using the PROC CORR command and the PROC STEPWISE command to verify the relevance of each variable and the formation of possible regression equations.

A multivariate statistical method was used (Pereira 2004) that allows the recognition of natural patterns in the data group. For this purpose, the Pirouette ${ }^{\circledR}$ statistical program was used, which allows the Hierarchical Cluster Analysis (HCA). Thus, it is possible to group the experimental units (cows) according to the similarity of the variables studied, by the Ward/Incremental method and the Euclidean distance. To delineate the number of groups formed by HCA, the following criteria were used: a) relevance of the group to explain the observed patterns; and b) minimum number of experimental units in each group.

Two population arrangements were performed (Figures 1 and 2), the difference between the arrangements being the inclusion of body weight at weaning, because it was not measured in all cows $(n=228)$. The groups from the HCA were submitted to unilateral analysis of variance by the PROC GLM procedure and the means were compared by Student's t-test with $\alpha=0.05$ probability. To better present the results, the groups formed by HCA were named differently, where the first arrangement were identified by Roman numerals (Figure 1) and the second arrangement in letters of the alphabet (Figure 2).

\section{RESULTS}

There was no interaction in the analysis of multiple variance (MANOVA) $(\mathrm{P}<0.05)$ for the variables analyzed between the genetic predominance with cow condition (postpartum rebreeding) in the 
following year. The variable that approached for interaction $(\mathrm{P}=0.08)$, in the unilateral analysis of variance (GLM), was the period of calving occurrence within the calving season. Considering the interaction, it was obtained that animals of both genetic, Charolais and Nellore predominance, repeat calving with calving date at the calving season of 36 and 34 days, respectively.

Variables (cow's age at calving, body condition score at calving, cow body weight at calving, calving date at calving season, cow body weight at weaning and cow body weight gain of calving-weaning) did not present a difference $(\mathrm{P}<0.05)$ between the Charolais and Nelore genetic predominance (Table I). Differently to the postpartum rebreeding where all variables were different $(\mathrm{P}<0.05)$ between the cows that repeat calving and did not repeat, where superiority was found in the means for all the variables for the group that repeat calving.

The groups formed by the HCA analysis are shown in Figures 1 and 2. The clear formation of the clusters can be observed from $60 \%$ similarity. Moreover, with similarity increase similar behaviors were observed between the Figures. This was verified by the formation of the groups in the following sequence of variables: previous calving condition (Empty vs. Pregnant), genetic predominance (Charolais vs. Nellore) and calving date in the calving season.
In the multiple regression analysis, it was also obtained that the variable with the greatest importance for the postpartum rebreeding, among those evaluated, is the calving date within the calving season. The following equations below:

$\mathrm{Y}=-0.00565 \mathrm{~A}+1.7071$

$\mathrm{n}=437 ; \mathrm{P}=<0.0001 ; \mathrm{R}^{2}=0.08 ; \mathrm{C}_{(\mathrm{p})}=35.4835$.

$\mathrm{Y}=-0,00644 \mathrm{~A}+1,86079$

$\mathrm{n}=228 ; \mathrm{P}=<0.0001 ; \mathrm{R}^{2}=0.11 ; \mathrm{C}_{(\mathrm{p})}=25.9925$.

$\mathrm{Y}=-0.00629 \mathrm{~A}+0.00247 \mathrm{~B}+0.93385$

$\mathrm{n}=228 ; \mathrm{P}=<0.0001 ; \mathrm{R}^{2}=0.20 ; \mathrm{C}_{(\mathrm{p})}=1.5468$.

$\mathrm{Y}=-0.00681 \mathrm{~A}+0.04536 \mathrm{C}+0.69846$

$\mathrm{n}=437 ; \mathrm{P}=<0.0001 ; \mathrm{R}^{2}=0.15 ; \mathrm{C}_{(\mathrm{p})}=8.6972$.

$\mathrm{Y}=-0.007 \mathrm{~A}+0.034 \mathrm{C}+0.00131 \mathrm{D}+0.48863$

$\mathrm{n}=437 ; \mathrm{P}=0.0078 ; \mathrm{R}^{2}=0.17 ; \mathrm{C}_{(\mathrm{p})}=3.5324$, where:

$\mathrm{Y}=$ condition (repetition or non-repetition of calving); $\mathrm{A}=$ the calving date within the calving season; $\mathrm{B}=$ cow $\mathrm{BW}$ at weaning; $\mathrm{C}=$ cow $\mathrm{BCS}$ at calving; and $\mathrm{D}=$ cow $\mathrm{PV}$ at calving.

It is observed that the variable calving date has a greater participation, determining $8 \%$ of the response in postpartum rebreeding $(n=437)$ or $11 \%(n=228)$ when we have the influence of the variable cow BW at weaning. On the other hand, the cow BW at weaning when included in the data set determined $9 \%$ of the postpartum rebreeding result $(n=228)$. In the larger data set $(n=437)$ the variables that determined significantly $(\mathrm{P}<0.05)$ the

TABLE I

Mean and standard error of age of cow at calving, body weight (BW) and body condition score (BCS) at calving, calving date at calving season, body weight at weaning, and body weight gain from calving at weaning (BWGCW) from cows of the evaluated herd.

\begin{tabular}{ccccccc}
\hline \multirow{2}{*}{ Variables } & \multicolumn{3}{c}{ Genetic predominance } & \multicolumn{3}{c}{ Cow condition } \\
\cline { 2 - 6 } & Charolais & Nellore & P & No repetition & With repetition & P \\
\hline Calving age, years & $4.44 \pm 0.11$ & $4.51 \pm 0.12$ & 0.6835 & $4.25 \pm 0.11$ & $4.73 \pm 0.12$ & 0.0037 \\
Calving BCS, points & $2.32 \pm 0.02$ & $2.35 \pm 0.02$ & 0.4920 & $2.28 \pm 0.02$ & $2.40 \pm 0.02$ & 0.0002 \\
Calving BW, kg & $369 \pm 4$ & $370 \pm 5$ & 0.8447 & $359 \pm 4$ & $380 \pm 4$ & 0.0005 \\
Calving date, days & $42 \pm 2$ & $44 \pm 2$ & 0.3480 & $50 \pm 2$ & $35 \pm 2$ & $<0.0001$ \\
Weaning BW, kg & $370 \pm 6$ & $377 \pm 6$ & 0.3963 & $349 \pm 6$ & $389 \pm 5$ & $<0.0001$ \\
BWGCW, kg & $5 \pm 2$ & $4 \pm 2$ & 0.6868 & $-1 \pm 3$ & $9 \pm 2$ & 0.0124 \\
\hline
\end{tabular}




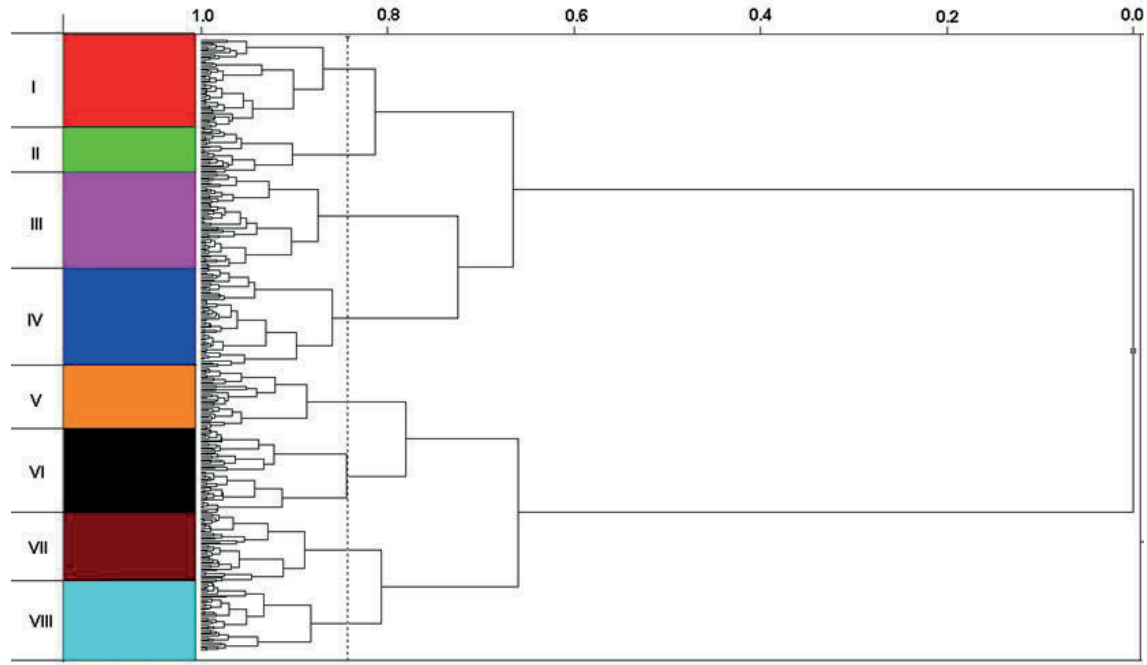

Figure 1 - Dendrogram obtained from the HCA using an X data matrix (347x6): Ward/ Incremental method and Euclidean distance. The dashed line indicates with $84.3 \%$ the similarity of the cows.

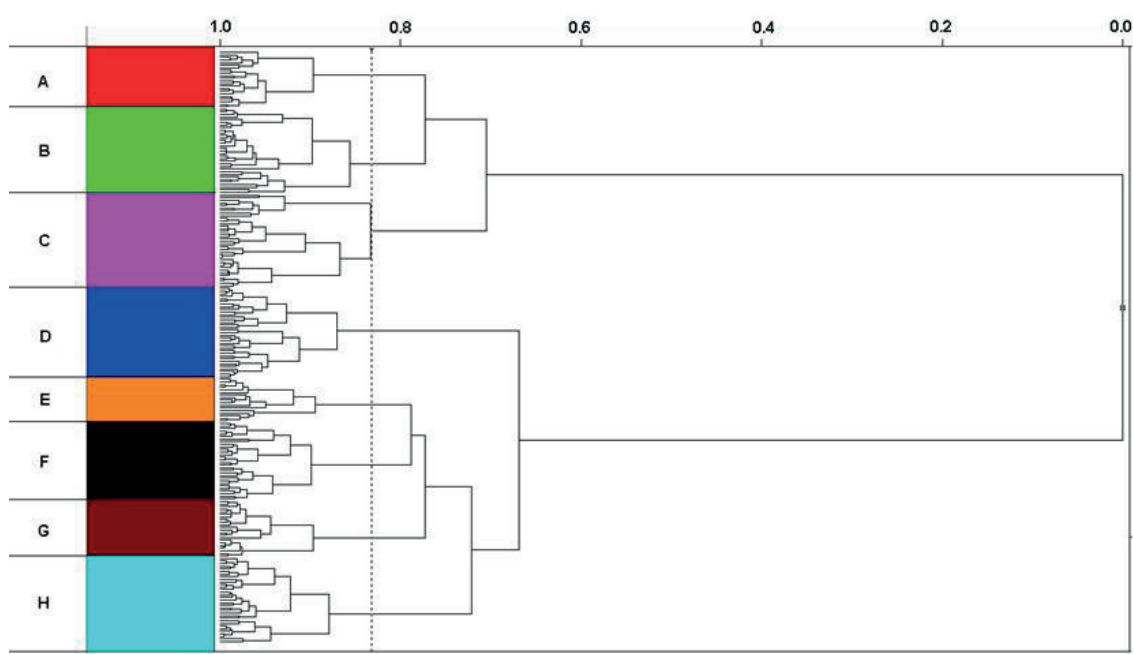

Figure 2 - Dendrogram obtained from the HCA using an X data matrix (228x7): Ward/ Incremental method and Euclidean distance. The dashed line indicates with $83.2 \%$ the similarity of the cows.

results in sequence were the calving date (8\%), cow BCS at calving (7\%) and cow BW at calving (2\%).

The cows that presented repetition of calving (Table II) presented mean age, body weight (BW) and body condition score (BCS) at calving higher than cows that did not show calving repetition in the following year. Among the groups formed, it can be observed that the period in which the calving occurred in the calving season obtained a clear distinction of three periods in each genetic predominance. The first period, located on average at 25 days, the second with 58 days and the last one, from cows that calving around the 67 days in the calving season. As cows that calving in the last period ( $>66$ days) did not show postpartum rebreeding without distinction between genetic 
predominance, even presenting calving BW and BCS similar to previous periods.

When cows calved at the beginning of the calving season with BW and BCS mean less than $338 \mathrm{~kg}$ (Group II) and 2.19 points (Group I), respectively, they are unable to postpartum rebreeding regardless of genetic predominance. With the improvement of calving BCS and BW, concomitant with the anticipation of calving in 7 days in the mean (Group VIII), cows with Nellore predominance presented the postpartum rebreeding at similar ages.

The increase in calving BCS mean of 0.14 points and the occurrence of calving occurring 9 days earlier at the calving season (Group V vs. Group III) gives the Charolais genetic predominance cows a new calf the following year. However, cows with Nellore predominance (Group VII vs. Group IV) presented adequate BCS at calving, but to conceive them the following year they would need to increase BW at calving by $23 \mathrm{~kg}$ on average and/ or calving 14 days earlier in the calving season of the previous year.

Table III shows the new group formation with the inclusion of the variable cow BW at weaning, where 8 groups were formed again (3 without repeat +5 with repeat). The inclusion of this variable caused a decrease in the size of the sample, since for some years it was not measured. Even though the groupings followed the same logic and relations as the first cluster analysis (Figure 1).

In this new approach, it can be observed that cows with Charolais predominance (Group B vs. Group G), even with intermediate calving BCS (2.32 points) and similar performance between calving and weaning, were not successful in postpartum rebreeding. It can be observed that the anticipation of calving in the previous season (11 days) and higher average daily gain of body weight $(0.053 \mathrm{~kg}$ vs. $0.160 \mathrm{~kg}$ ) from calving-weaning, mean between these groups, gives rise to postpartum rebreeding.

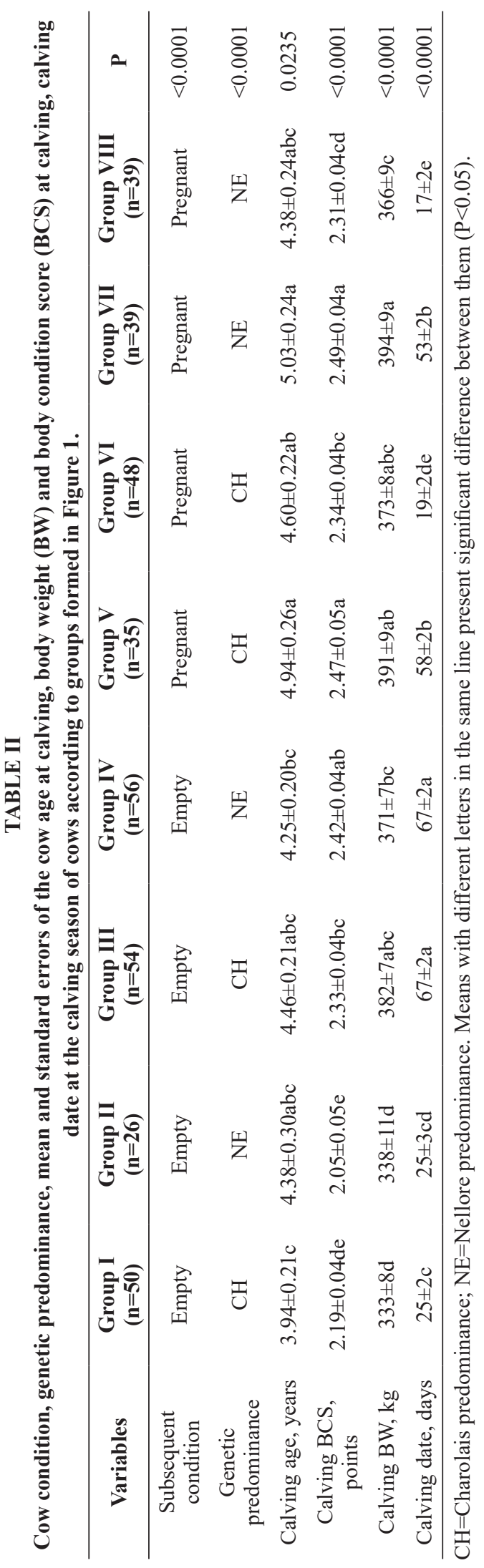




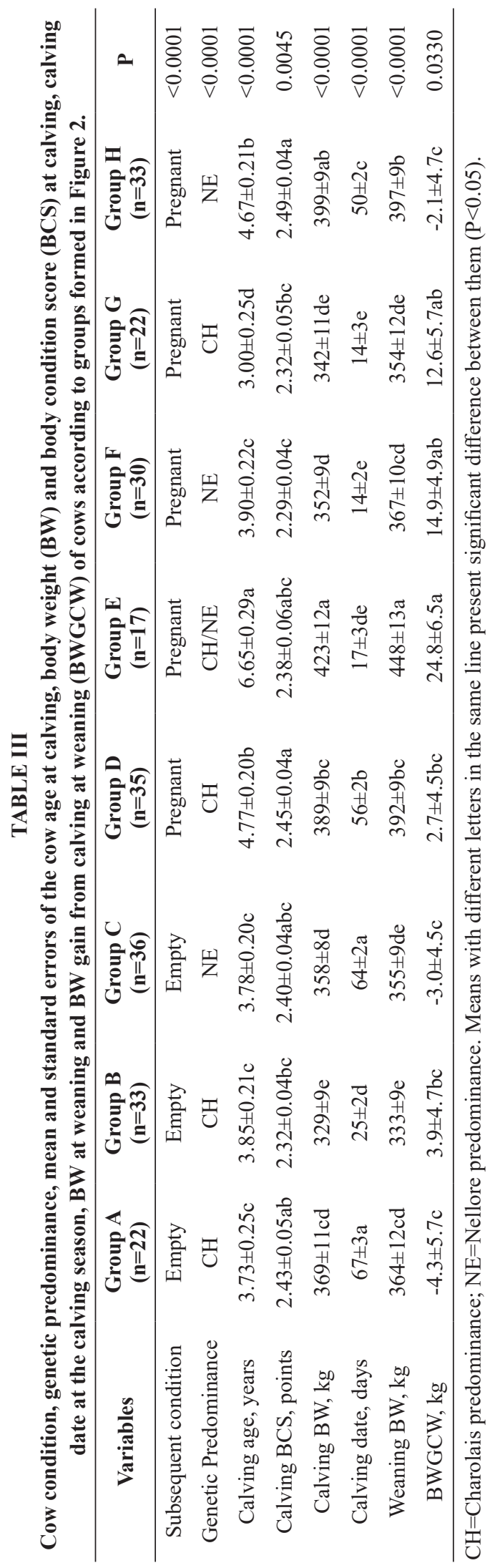

The Nellore genetic predominance when they had similar calving BCS (2.32 points) (Group $\mathrm{H} v s$. Group C) and presented negative body weight gain at calving-weaning (BWGCW) $(-3.0 \mathrm{~kg}$ and -2.1 $\mathrm{kg}$ ) showed different results. They did not obtain the postpartum rebreeding, when these calved with smaller BW and also lower BW at weaning (Group C). However, when cows of this predominance (Group F) calved at the beginning of the calving season (mean 14 days), even with lower BCS at calving (2.29 points) and BW at calving (352 kg) and weaning (367 kg) achieved positive results because they presented better BWGCW $(14.9 \mathrm{~kg})$.

When comparing cows who repeat calving and calving between 50 and 56 days (Group D vs. Group H) at the previous calving season, it is noted that the anticipation of calving within the calving season favors cows with Nellore predominance, even losing BW from calving at weaning $(-2.1 \mathrm{~kg})$. Different from cows of Charolais predominance that presented small gain of BW from calving at weaning $(2.7 \mathrm{~kg})$.

\section{DISCUSSION}

When the bovine reproduction is evaluated, the relationship between BW and BCS is verified for the success of the postpartum rebreeding (Table I). The inefficiency of one of these variables has problems with the reproductive process in the herd. According to Vieira et al. (2005), cows managed in pastoral systems with BCS above 3 points can obtain high pregnancy rates. The high pregnancy rate can be related to the good physical condition (BW and BCS) thus reducing the period of physiological recovery, reducing the interval between calving. The BCS at calving in Groups III (2.33 points) and V (2.47 points) and the BW at calving in Groups IV (371 kg) and VII (394 kg) can be observed in Table II, and it is necessary to maintain the balance between them to achieve better 
results in reproductive efficiency and consequently economic of the livestock activity.

Pregnancy rates of 40 and $51 \%$ were consecutively obtained by Almeida et al. (2002), when they evaluated the postpartum rebreeding of cows (3-9 years old) submitted to precocious weaning and that presented $402 \mathrm{~kg}$ of BW and 2.4 points BCS at the end of the first mating season, and the animals showed a gain of BW $(0.828 \mathrm{~kg} /$ day) from weaning at the end of mating season. The reproductive function is decreased as the cow presents loss of $\mathrm{BW}$ during mating and/ or very low calving BCS that does not allow its recovery until the end of the next mating season. Body fat is of great importance for the production of leptin, the hormonal trigger of reproduction, for releasing luteinizing hormone (Liefers et al. 2003). BW losses during mating $(-0.160 \mathrm{~kg} /$ day $)$ were also reported by Grecellé et al. (2006) as responsible for the low pregnancy rate obtained in her study, even presenting a good initial BW $(392.9 \mathrm{~kg}$ ). The loss of BW during mating was caused by the dietary deficiency through which the cows passed during that period. Reflecting thus directly on the pregnancy rate and consequently on the reproductive efficiency of the herd, where the authors concluded that the entry of animals into the mating season with low BW, associated with BCS, and the consequent loss of weight during mating were the factors determining the pregnancy rate.

In addition to the loss of BW during the mating season, it can occur loss of BW from calving until the beginning of the mating season, a period that increases the nutritional demand for milk supply to the calf. The major postpartum issue involves the peak milk production weeks before the peak of food intake (Sartori and Guardieiro 2010), as the rumen gradually returns to occupy the ventral space left by the calf at calving. The energy demand of a cow, $533 \mathrm{~kg}$ and average age, at the peak of lactation is 16 $\mathrm{Mcal} /$ day considering its maintenance of BW and production of $8 \mathrm{~kg}$ of milk at peak lactation. Then milk production $(5.74 \mathrm{Mcal} /$ day) and maintenance of BW (10.25 Mcal/day) are the main energy demands of postpartum cows, where the peak milk production occurs around 45 days (NRC 2001). The use of precocious weaning in the herd, as submitted to the animals evaluated in this article, decreases the energy requirement for milk production. Thus, the energy demand decrease by $35 \%$ at 60 days of lactation and decreases the relation as time moves away from the lactation peak.

The search for the anticipation of calving within the calving season is one of the outlets that can be had, because it increases the period in which the cow has to recover the $\mathrm{BW}$ and increase the deposition of body fat. To ensure early calving at the calving season, the rural enterprise needs fodder planning, taking into account the nutritional demands that the animals will have during the different physiological states.

Selecting replacement heifers also becomes important for the reproductive process triggering positive results in the breeding system. According to Funston et al. (2012), the selection of future breeding cows can not only take into account age or BW. Therefore, the authors suggest that the selection in the first diagnosis of gestation is more important than the selection based on the age of the heifers. Firstly, all replacement heifers would produce at least one calf, considering that there may still be some loss until calving, reducing the production cost of replacement heifers. Even though heifers show calving, age cannot be considered as the sole fertility screening tool (Funston et al. 2012).

For the rearing herd Grecellé et al. (2006) obtained effect of the calving date $(\mathrm{P}=0.0736)$ on the probability of the cow being pregnant. The authors also found that the pregnancy rate declined according to the occurrence of later calving at the calving season, where the chance of conception decreased by $11.4 \%$ for every 10 days at the calving season. The reduction in pregnancy rate was also found by Pimentel and Pimentel (1983), but at a 
magnitude of $5.1 \%$ for every 10 days at the calving date at the calving season.

The occurrence of parturition at the beginning of the calving season provides a longer period in days for the recovery of BW and BCS that allow the beginning of a new reproductive cycle. Even with $\mathrm{BW}$ and BCS less than cows that calving later in the calving season, these have more days for physical recovery until the beginning of mating season. The effect of early calving on postpartum rebreeding is greater than the animal performance rate $(\mathrm{kg} /$ day) until the beginning of mating season. In cows that calved at the beginning of the calving season, they will show the peak of lactation before the other cows that calved later, so they no longer have the negative effect of lactation in relation to energy demand (Grecellé et al. 2006). Also, the same authors recommend that the mating season be adequate for a maximum of 90 days duration and that coincide with the forage availability of the farm. Larson and White (2016) indicate that, in order to improve the reproductive indices of the highly qualified rural enterprise, the best period for the mating season is 63 days for multiparous cows. By enabling the cows, under sanitary and nutritional conditions served, to present at least 3 cycles for fertilization, thus allowing greater selection pressure of the herd.

In different BW groups of heifers and pastoral feeding management in the Pampa biome, Menegaz et al. (2008) found significant differences $(\mathrm{P}<0.05)$ in the mean conception date and its design speed. Where heifers managed in an improved native field had a shorter reproduction-conception interval (30.58 days) than those conducted only in the native field (36.47 days) and native field with supplementation (39.44 days). Regarding the BW groups (heavy, medium and light), heifers of the heavy group presented a significant difference $(\mathrm{P}<0.05)$ in relation to the others with the shortest interval (29.86 days). However, Beretta and Lobato (1996) did not corroborate, as they did not present a significant difference between the date of conception, weight groups, racial type and pastoral feeding, which presented a reproductionconception interval of 26.6 (subgrazing) and 27.5 (overgrazing) \pm 14.3 days. Vieira et al. (2006) obtained the distribution of similar calving according to feeding management and weight groups, $52 \%$ of heifers conceived $<31$ days, $26 \%$ between 32-62 days of the reproductive period and $23 \%>63$ days. However, they found an effect of $\mathrm{BW}$ of heifers with the evaluated years, where they had a lower pregnancy rate and a longer interval calving-conception in the group of heifers with lower PV.

According to Funston et al. (2012) the distribution of calving at the beginning of the breeding season brings more benefits to the farmer, in addition to the direct reproductive efficiency obtained by the largest number of calves weaned per cow/year. The authors reported in their study that calves from heifers that were born in the first 21 days of the calving season compared to those born $>42$ days had a higher BW at weaning, beginning mating and prepartum, higher percentage cycling before the mating season and higher pregnancy rate. Thus, the producer can select heifers for greater reproductive efficiency, since the calving period of the heifer progeny causes significant impacts on the development and characteristics of the first calving/calf. According to the same authors, the calf of the first calving, originating from heifers that gave birth $<21$ days, also present an early calving date and higher BW at weaning. Still in their study, Funston et al. (2012) observed that steers that are also born at the beginning of the calving season present greater BW at weaning, warm carcass weight and marbling score.

In this study, when cows calved at the beginning of the calving season with low BW and BCS, even though they had a longer period available for body and physiological recovery, they were not able to guarantee postpartum rebreeding, especially 
in primiparous animals. The period in which the calving occurred also correlated $(21.77 \%)$ with the BCS at calving.

Cows may still show positive productive performance between calving and weaning, but they were not sufficient to ensure a new pregnancy. The mean conception of $41 \pm 3$ days were found by Moura et al. (2014) when they weaned precocious in cows that presented BW loss of $15.24 \mathrm{~kg}$ from calving at the beginning of the mating season, but that by the end of the mating season they obtained a BW gain of $39.02 \mathrm{~kg}$. The BW gain of cows from calving-weaning presented a negative correlation $(31.76 \%)$ with the calving date within the calving season. Daily BW gains of $0.5 \mathrm{~kg}$ were described by Moura et al. (2014) during the mating season and increased by 0.54 points in the BCS when they evaluated cows in three weaning systems, triggering pregnancy rates above $90 \%$.

Adequate forage availability and that can offer positive BW gain and deposition of body fat, consequently formation of adipocytes that trigger the formation of leptin, which in turn will act on the metabolic hormonal network (insulin, GH, IGF-I and II) that will increase the frequency of the LH pulse (Souza et al. 2009).

The result of the calving season of the following year depends very much on the distribution of calves in the previous calving season, where obtaining higher conception indices at the beginning of the mating season increases the result in the pregnancy rate in the following year. Animals that calved until the second third of the calving season (Groups D and $\mathrm{H}$ ) had enough $\mathrm{BW}$ and $\mathrm{BCS}$ at calving and were able to maintain these conditions until weaning had the possibility of postpartum rebreeding, as occurred in this study. Interval for design less than 50 days, counted from the start of the mating season, were obtained by Moura et al. (2014) who evaluated cows with good ECC submitted to three different models of weaning.
According to Short et al. (1990) and Cushman et al. (2007) cows that later calved at the calving season have the lowest postpartum anestrus period, allowing better opportunities to restart reproductive cycles at conception time. Animals that calved at the beginning of the calving season are more likely to conceive a new calf the following year (Thorpe et al. 1980). Because the cows have more time to recover BCS until the beginning of the next mating season (Grecellé et al. 2006). Still Teixeira et al. (1997) evaluated more than 48.000 calving, observed higher postpartum rebreeding (80\%) in cows that calved earlier in the calving season. The productivity of cows that calved early in the calving season is higher during their reproductive life, since they wean a larger number of calves with high BW (Azeredo et al. 2007).

Increases in BW of weaned calves were described by Cushman et al. (2013a) for cows that calved earlier in the calving season. The authors describe that this increase was that ascended to the extra production of calves during the reproductive life of the cow in the herd. By making the farmer have a financial advantage of the breeding system and making it clear to the farmer that it is important to ensure that replacement heifers conceive as soon as possible within the calving group. Decrease in pregnancy rate and $\mathrm{kg}$ of calves weaned by cow exposed to herd reproduction are caused by long postpartum intervals that decrease the proportion of cows with reproductive cycles at the beginning of the mating season. Even cows that calved after 40 days from the calving season leave the herd prematurely when compared to contemporary cows that calving to the same number of calves Cushman et al. (2013b).

In conclusion, cows that calved at the beginning of the calving season are more likely to be postpartum rebreeding because they have more time to recover physically and physiologically.

The low body weight and body condition score of the cow at calving impairs the postpartum 
rebreeding of cows with predominance of Charolais and Nellore, respectively, which calved at the beginning of the calving season. Even as they present higher values for these characteristics, their chances of repetition are increased as the calving at the calving season advances.

\section{REFERENCES}

ALMEIDA LSP, LOBATO JFP AND SCHENKEL FS. 2002. Data de desmame e desempenho reprodutivo de vacas de corte. R Bras Zootec 31(3): 1223-1229.

ALVARES CA, STAPE JL, SENTELHAS PC, GONÇALVES JLM AND SPAROVEK G. 2013. Köppen's climate classification map for Brazil. Meteorol Z 22(6): 721-728.

AZEREDO DM, ROCHA DC, JOBIM MIM, MATTOS RC AND GREGORY RM. 2007. Efeito da sincronização e da indução de estros em novilhas sobre a prenhez e o índice de repetição de crias na segunda estação reprodutiva. Ciênc Rural 37: 201-205.

BERETTA V AND LOBATO JFP. 1996. Efeito da ordem de utilização de pastagens melhoradas no ganho de peso e comportamento reprodutivo de novilhas de corte. R Bras Zootec 25(6): 1205-1215.

CUSHMAN RA, ALLAN MF, THALLMAN RM AND CUNDIFF LV. 2007. Characterization of biological types of cattle (Cycle VII): Influence of postpartum interval and estrous cycle length on fertility. J Anim Sci 85: 2156-2162.

CUSHMAN RA, KILL LK, FUNSTON RN, MOUSEL EM AND PERRY GA. 2013b. Heifer calving date positively influences calf weaning weights through six parturitions. J Anim Sci 91: 4486-4491.

CUSHMAN RA, MILES JR, REMPEL LA, MCDANELD TG, KUEHN LA, CHITKO-MCKOWN CG, NONNEMAN D AND ECHTERNKAMP SE. 2013a. Identification of an ionotropic glutamate receptor AMPA1/GRIA1 polymorphism in crossbred beef cows differing in fertility. J Anim Sci 91: 2640-2646.

FUNSTON RN, MUSGRAVE JA, MEYER TL AND LARSON DM. 2012. Effect of calving distribution on beef cattle progeny performance. J Anim Sci 90: 5118-5121.

GRECELLÉ RA, BARCELLOS JOJ, BRACINI NETO J, COSTA EC AND PRATES ER. 2006. Taxa de prenhez de vacas Nelore $X$ Hereford em ambiente subtropical sob restrição alimentar. R Bras Zootec 35(4): 1423-1430.

LARSON RL AND WHITE BJ. 2016. Reproductive systems for north american beef cattle herds. Vet Clin Food Anim 32: $249-266$.

LIEFERS SC, VEERKAMP RF, PAS MFW, DELAVAUD C, CHILLIARD Y AND VAN DER LENDE T. 2003. Leptin: concentrations in relation to energy balance, milk yield, intake, live weight and estrus in dairy cows. J Dairy Sci 86: 799-807.

LOWMAN BG, SCOTT N AND SOMERVILLE S. 1973. Condition scoring beef cattle. Edinburgh: East of Scotland College of Agriculture. (Bulletin 6), 8 p.

MENEGAZ AL, LOBATO JFP AND PEREIRA ACG. 2008. Influência do manejo alimentar no ganho de peso e no desempenho reprodutivo de novilhas de corte. R Bras Zootec 37(10): 1844-1852.

MORAES JCF, SOUZA CJH, BRAUNER CC, PIMENTEL MA, BENAVIDES MV AND FERRAZ JBS. 2013. Use of postpartum body condition score to identify the most fertile beef cows raised in extensive conditions. Arch Latinoam Prod Anim 21(3): 149-155.

MOURA ICF, KUSS F, MOLETTA JL, MENEZES LFG, HENRIQUE DS, LIPINSKI LC AND MARTINS AS. 2014. Desempenho de vacas de corte Purunã submetidas a diferentes manejos de amamentação. Pesq Agropec Bras 49(1): 49-56.

MULLINIKS JT, COX SH, KEMP ME, ENDECOTT RL, WATERMAN RC, VANLEEUWEN DM AND PETERSEN MK. 2012. Relationship between body condition score at calving and reproductive performance in young postpartum cows grazing native range. J Anim Sci 90: 2811-2817.

NRC - NATIONAL RESEARCH COUNCIL. 2001. Nutrient requirements of dairy cattle, $7^{\text {th }}$ ed., Washington.

PEREIRA JCR. 2004. Análise de dados qualitativos: estratégias metodológicas para as ciências da saúde, humanas e sociais. São Paulo: EDUSP, $3^{\mathrm{a}}$ ed., 156 p.

PIMENTEL CA AND PIMENTEL MA. 1983. Efeito do mês de parição sobre a função reprodutiva de vacas de corte. Rev Bras Reprod Anim 7(1): 33-42.

PRIYADARSHINI L, YADAV AK, SINGH HS, MISHRA A, JAIN AK AND AHIRWAR MK. 2015. Role of leptin in physiology of animal reproduction - A review. Agricultural Reviews 36(3): 235-240.

RECOULES E, DE LA TORRE A, AGABRIEL J, EGAL D AND BLANC F. 2013. Subcutaneous body lipids affect cyclicity and estrus behavior in primiparous Charolais cows. Anim Reprod Sci 140: 115-123.

SARTORI R AND GUARDIEIRO MM. 2010. Fatores nutricionais associados à reprodução da fêmea bovina. $\mathrm{R}$ Bras Zootec 39: 422-432.

SAS - STATISTICAL ANALYSIS SYSTEM. 2009. SAS Language Reference. Version 9.2. Cary, North Carolina.

SHORT RE, BELLOWS RA, STAIGMILLER RB, BERARDINELLI JG AND CUSTER EE. 1990. Physiological mechanisms controlling anestrus and infertility in postpartum beef cattle. J Anim Sci 68: 799816.

SILVEIRA MF, RESTLE J, ALVES FILHO DC, MISSIO RL, DONICHT PAMM, SEGABINAZZI LR, CALLEGARO 
AM AND JONER G. 2014. Protected fat supplementation for early weaned beef cows maintained in nature pasture. Arq Bras Med Vet Zoo 66(3): 809-817.

SOUZA FA, CANISSO IF, BORGES AM, VALE FILHO VR, LIMA AL AND SILVA EC. 2009. Restrição alimentar e os mecanismos endócrinos associados ao desenvolvimento folicular ovariano em vacas. R Bras Reprod Anim 33: 6165.

TANURE S, PÖTTER BAA AND LOBATO JFP. 2011. Natural and improved natural pastures on the reproductive performance of first-calf beef cows. R Bras Zootec 40(3): 690-699.
TEIXEIRA RA, PITA FVC, ALBUQUERQUE LG AND FRIES L. 1997. Efeito da época de parição sobre os índices de fertilidade em vacas Nelore. Uberaba, Brasil, $4^{\mathrm{a}}$ ed., $27 \mathrm{p}$.

THORPE W, CRUICKSHANK DKR AND THOMPSON R. 1980. Genetic and enviromental influences on beef cattle production in Zambia 1. Factors affecting weaner production from Angoni, Barotse and Boran dams. Anim Prod 30(2): 217-234.

VIEIRA A, LOBATO JFP, TORRES JUNIOR RAA, CEZAR

IM AND CORREA ES. 2005. Fatores determinantes do desempenho reprodutivo de vacas Nelore na região dos Cerrados do Brasil Central. R Bras Zootec 34: 2409-2416. 